J. Product. \& Dev., 19(3):313 - 332(2014)

\title{
BIO-FERTILIZATION AND ITS IMPACT ON QUALITY AND PRODUCTIVITY OF SOME NEW PEA (PISUM SATIVUM L.) CULTIVARS
}

\author{
W. M. Abdel-Hakim; ${ }^{* * *}$ Y. M.M. Moustafa ${ }^{* * *}$ and K. A.M. Nour \\ ${ }^{*}$ Self-Pollination Vegetable Res. Dept., Hort. Res. Inst., ARC, Giza, Egypt \\ *** Department of Horticulture, Faculty of Agriculture, Minia University, \\ Minia, Egypt. \\ **Corresponding author: yasser.mostafa@mu.edu.eg
}

\begin{abstract}
Three different pea cultivars Master B، Jaguar and Palmoral were used in this investigation to study the effect of cultivars and different doses of $N$ mineral fertilization along with three isolates of $\mathrm{N}_{2}$-fixing bacteria (Rhizobium) on growth, yield and chemical composition of those cultivars. Results showed that the three cultivars varied in their flowering time and yield production and almost behaved different under mineral and bio-fertilization. The biofertilization increased the plants vegetative growth, yield and yield components. Furthermore, the bio-fertilization increased the quality of seeds and their protein content, but reduced their contents of nitrate and nitrite in comparison with those fertilized by $N$ mineral fertilization only.
\end{abstract}

Key words: Peas, New Cultivars Evaluation, Mineral and BioFertilizations, Organic Production.

\section{INTRODUCTION}

Field pea (Pisum sativum L.) derives from the Middle East and was first cultivated roughly 10,000 years ago (Mithen, 2003; Gad El-Hak et al., 2012). Pea is a very nutritious vegetable grown in the cool season in different regions of the world. It is grown as a vegetable crop for both fresh and dried seeds. Pea contains high percentage of digestible protein, along with carbohydrates and vitamins (Davies et al., 1985 and Akhilesh and Singh, 2013). A wide range of genetic variability is available in pea, providing a good scope for improvement in yield and associated characters of pea through selection. Selection among cultivars and lines for different purposes is very crucial nowadays (Gheeth et al., 2012).

It has been recognized that fertilizers are effective means to increase the yield of vegetable crops and to reduce the shortage in food supplies 
especially in countries with population of high density. Bio-fertilizers are microorganisms that help plants to grow by increasing the quantity of available nutrients. Since these fertilizers contain living microorganisms it increases or promotes the supply of important nutrients crucial for the overall productivity of the soil. Recent attention has been given to reduce soil pollution practices in modern agriculture. One of the ways to reduce soil pollution is the use of bio-fertilizers which have been recommended by several investigators to substitute partially chemical fertilizers (Saber, 1993, El-Agory et al., 1996 ; Hanafy et al., 2000).

Among the most important agricultural treatments that affect crops yield of unit area nitrogen fertilization. Nitrogen is the most commonly used mineral nutrient, which is important for protein production. It plays a pivotal role in many critical functions such as photosynthesis in the plant and is a major component of proteins containing amino acids used in forming protoplasm, cell division and plant growth. Nitrogen is necessary for enzymatic reactions in plants since all plant enzymes are proteins. It is a necessary component of several vitamins, e.g., thiamine, niacin and riboflavin and is a part of the nucleic acids; i.e. DNA and RNA (Marschner, 1995).

Therefore, the present study aimed to evaluate three pea cultivars and investigate the effect of $\mathrm{N}$ mineral fertilization and/or three Isolates of biofertilizers (Minia Azotein) on pea plant growth, chemical composition and green pod yield and its components as well as dry seed yield and seeds quality. Moreover, the study aimed to decrease the pollution resulting from using mineral fertilizers by the application of bio fertilizers and encourage the organic production of pea in Egypt.

\section{MATERIALS AND METHODS}

Two field experiments were carried out at the Experimental Farm of Mallawy Agricultural Research Station, Minia Governorate, Egypt, during the two successive winter seasons of 2010/2011 and 2011/2012, respectively to evaluate the effect of three strains of $\mathrm{N}_{2}$-fixing bacteria as a bio-fertilizer (Minia Azotein; was friendly obtained from Minia University Bio-fertilization Center, Minia, Egypt) in addition to different levels of mineral $\mathrm{N}$ fertilizer on growth and chemical constituents of three Pea (Pisum sativum L.) cultivars; namely Master B, Palmoral and Jaguar. Soil analysis was carried out according to Wilde et al. (1985) and the averages of the obtained data are shown in Table 1. 
Table 1: Physical and chemical analyses of the experimental soil (average two seasons).

\begin{tabular}{ll}
\hline \multicolumn{1}{c}{ Soil constituents } & \multicolumn{1}{c}{ Value } \\
\hline Texture grade & Clay loam \\
Sand & $7.15 \%$ \\
Silt & $54.25 \%$ \\
Clay & $38.60 \%$ \\
pH $(1: 2.5$ soil suspension) & 8.16 \\
E.C. $\left(\mathrm{dsm}^{-1}, 1: 5\right.$ soil water extract) & 1.17 \\
$\mathrm{CaCO}_{3}$ & $3.20 \%$ \\
Organic matter & $1.40 \%$ \\
Available N & $45.18 \mathrm{ppm}$ \\
Available P & $11.37 \mathrm{ppm}$ \\
Available K & $78.16 \mathrm{ppm}$ \\
\hline E.C.: Electrical Conductivity. &
\end{tabular}

Pea seeds were sown on November $5^{\text {th }}$, in 2010 and November $8^{\text {th }}$, in 2011, respectively on one side of line ridge ( $4 \mathrm{~m}$ long and $60 \mathrm{~cm}$ wide). Seeds were drilled at spacing averaged $10 \mathrm{~cm}$ apart. Each experimental plot consisted of 4 ridges, so the area of each plot was $9.6 \mathrm{~m}^{2}$. Mineral nitrogen was applied in the form of ammonium sulfate $(20.6 \% \mathrm{~N})$ at four levels $(0.0,25,50$ and $100 \%)$ with or without bio-fertilizers. Phosphorus in the form of calcium super phosphate $\left(15.5 \% \mathrm{P}_{2} \mathrm{O}_{5}\right)$ at $31 \mathrm{~kg} / \mathrm{fed}$. and potassium in the form of potassium sulfate $\left(48 \% \mathrm{~K}_{2} \mathrm{O}\right)$ at the rate of $50 \mathrm{~kg} \mathrm{~K} \mathrm{~K}_{2} \mathrm{O} / \mathrm{fed}$. The different amounts of fertilizers were added at two equivalent doses after two and six weeks from seed sowing. The bio-fertilizers were applied to pea plants after three weeks from sowing. These treatments were arranged in split plot design with three replicates, pea cultivars were assigned at random in the main plots, while sub plots were devoted to levels of mineral $\mathrm{N}$ fertilizer and $\mathrm{N}_{2}$-fixing bacteria.The study included 30 treatments as follows:

Recommended doses of mineral N was (40 kg N/fed (about $200 \mathrm{~kg}$ of ammonium sulfate $(20.6 \% \mathrm{~N}) 500 \mathrm{~g}$ for each plot) without any inoculation of bio-fertilizers.

\section{Statistical design}

Each experiment consisted of two factors (pea cultivars, bio-fertilizer isolates, and/or the added doses of mineral $\mathrm{N}$ fertilizers) in a split design, where cultivars were in the main plots, the combination of isolates and the mineral nitrogen doses were in the sub plots. 
Data Recorded:

Vegetative Growth Characters: A random sample of five plants from each experimental plot was taken at full blooming stage; i.e., after 60 days from sowing seeds. The following data were recorded: Plant height and number of branches / plant.

Flowering Behavior: Number of days from sowing till the appearance of the first flower was determined in representative samples of three plants which were labeled at each plot for this purpose.

Harvesting Time: Averages days taken by the green and dry pods from plantation time to ripen and to be ready for harvesting were recorded for all treatments of the three cultivars are shown in Table 2.

Table 2: Harvesting time (days) of green pods and dry seeds of the three pea cultivars

\begin{tabular}{lcccc}
\hline \multicolumn{4}{c}{ Days to harvest } & \\
\hline Season & Fresh yield & & \\
& Cultivar & $\begin{array}{c}\text { First } \\
\text { harvest }\end{array}$ & $\begin{array}{c}\text { Second } \\
\text { harvest }\end{array}$ & $\begin{array}{c}\text { Dry yield+ } \\
\text { (2-5day) }\end{array}$ \\
\hline \multirow{3}{*}{ First season } & Master B & 87 & 100 & 135 \\
& Palmoral & 115 & 127 & 163 \\
& Jaguar & 101 & 115 & 148 \\
\hline \multirow{3}{*}{ Second season } & Master B & 88 & 102 & 142 \\
& Palmoral & 118 & 129 & 172 \\
& Jaguar & 104 & 117 & 157 \\
\hline
\end{tabular}

Green Pod Yield and Its Components: At harvest time, reproductive characteristics were recorded by using green pods taken from each plant and/or plot, hence, the average number of green pods/plant, green pods yield/plant (g) and total yield of green pods (ton/fed.) were recorded.

Physical and Chemical Fruit Quality: In order to record the physical pod characters, random samples of 20 pods were taken from each plot and the following data were recorded: average pod length $(\mathrm{cm})$ and pod weight $(\mathrm{g})$, number of seeds/pod, weight of 1000 dry seeds(g), and dry seed yield/fed.(Ton).

\section{Chemical Composition of Dry Seeds}

NPK determination: $\mathrm{N}, \mathrm{P}$ and $\mathrm{K}$ were determined in the dry seeds of all cultivars treatments the total nitrogen was determined in the digested dry matter of seeds using the micro-kjeldahl method according to Pregl (1945). Phosphorus was determined by using the spectrophotometer method as 
described by John (1970). Potassium was determined by using the flame photometer method as described by Brown and Lilliland (1946).

Crude protein $(\mathrm{N} \% \times 6.25)$ it was determined according to AOAC (2005). All determinations were performed in triplicates and the means were recorded.

Extraction and determination of nitrite and nitrate: the nitrite and nitrate were extracted from finally powdered meal of all samples by $1 \% \mathrm{~K}_{2} \mathrm{SO}_{4}$ solution and determined spectrophotometrically as described by Saad (1991).

\section{Statistical Analysis:}

All recorded data were subjected to the statistical analysis of variance procedures and treatment means were compared using the L.S.D as described by Gomez and Gomez (1984). The statistical analysis was done using the computer program MSTAT-C software version 4.0.

\section{RESULTS}

Generally, the three evaluated pea cultivars varied in their field performance, horticultural characteristics, yield and chemical prosperities. The three bacterial Isolates used in this study also varied in their effect on pea plants growth, yield and chemical composition. Furthermore, the best data values were obtained when $50 \%$ of $\mathrm{N}$ was used in combination with the bacterial bio-fertilization. On the other hand, plants bio-fertilized with Isolate 1 without any mineral $\mathrm{N}$ fertilization gave the lowest mean values in almost all of the studied characteristics.

\section{Growth Characters}

\section{Effect of cultivars}

Data presented in Table 3 show that the highest plants were observed by Palmoral cultivar $(88.7$ and $90.1 \mathrm{~cm})$ followed by Jaguar cultivar $(81.9$ and $82.7 \mathrm{~cm})$ while, Master B cultivar gave the shortest plants $(70.1$ and $71.9 \mathrm{~cm}$ ) in the first and second seasons, respectively, with significant differences among the three cultivars. Regarding number of branches per plant, it is clear from the same data that Palmoral cultivar gave the highest values (4.32 and 4.32) followed by Jaguar cultivar (3.37 and 3.32), while, Master B recorded the lowest values in this respect (2.56 and 2.48) in the first and second seasons, respectively with significant differences among them. As for flowering time, this character means the number of days elapsed from sowing seeds till the appearance of the first flower on pea plant, it is obvious from the data in Table 3 that $c v$. Master B was the 
Table 3: Effect of bio- and/or mineral $\mathrm{N}$ fertilization on growth characters of three pea cultivars, during 2010/2011 and 2011/2012 seasons

\begin{tabular}{|c|c|c|c|c|c|c|}
\hline \multirow{3}{*}{ Treatments } & \multicolumn{6}{|c|}{ Growth characters / plant } \\
\hline & \multicolumn{2}{|c|}{$\begin{array}{l}\text { Plant height } \\
\text { (cm) }\end{array}$} & \multicolumn{2}{|c|}{$\begin{array}{c}\text { Number of } \\
\text { branches }\end{array}$} & \multicolumn{2}{|c|}{$\begin{array}{c}\text { Flowering time } \\
\text { (day) }\end{array}$} \\
\hline & $\begin{array}{c}1^{\text {st }} \\
\text { season }\end{array}$ & $\begin{array}{c}2^{\text {nd }} \\
\text { season } \\
\end{array}$ & $\begin{array}{c}1^{\text {st }} \\
\text { season } \\
\end{array}$ & $\begin{array}{c}2^{\text {nd }} \\
\text { season } \\
\end{array}$ & $\begin{array}{c}1^{\text {st }} \\
\text { season }\end{array}$ & $\begin{array}{c}2^{\text {nd }} \\
\text { season } \\
\end{array}$ \\
\hline & \multicolumn{6}{|c|}{ Pea cultivars } \\
\hline Master B & 70.1 & 71.9 & 2.56 & 2.48 & 33.6 & 34.9 \\
\hline Palmoral & 88.7 & 90.1 & 4.32 & 4.32 & 56.8 & 57.7 \\
\hline Jaguar & 81.9 & 82.7 & 3.37 & 3.32 & 46.2 & 47.3 \\
\hline \multirow{2}{*}{ L.S.D at $5 \%$} & 2.41 & 1.14 & 0.25 & 0.09 & 0.09 & 0.11 \\
\hline & \multicolumn{6}{|c|}{ bio- and mineral $N$ fertilization } \\
\hline $100 \%$ mineral $\mathrm{N}$ & 81.1 & 80.0 & 3.25 & 3.16 & 46.7 & 47.3 \\
\hline Isolate $1+0 \% \mathrm{~N}$ & 72.9 & 74.6 & 2.90 & 2.97 & 44.3 & 45.8 \\
\hline Isolate $1+25 \% \mathrm{~N}$ & 84.2 & 86.0 & 3.60 & 3.50 & 45.3 & 46.6 \\
\hline Isolate $1+50 \% \mathrm{~N}$ & 88.3 & 90.4 & 4.24 & 4.10 & 45.6 & 46.9 \\
\hline Isolate $2+0 \% \mathrm{~N}$ & 70.2 & 72.2 & 2.87 & 2.93 & 44.4 & 45.6 \\
\hline Isolate $2+25 \% \mathrm{~N}$ & 83.6 & 85.2 & 3.55 & 3.42 & 45.3 & 46.4 \\
\hline Isolate $2+50 \% \mathrm{~N}$ & 87.8 & 90.0 & 4.17 & 4.02 & 45.7 & 46.7 \\
\hline Isolate $3+0 \% \mathrm{~N}$ & 67.3 & 69.3 & 2.73 & 2.80 & 45.6 & 46.8 \\
\hline Isolate $3+25 \% \mathrm{~N}$ & 82.3 & 82.8 & 3.27 & 3.23 & 46.2 & 47.2 \\
\hline Isolate $3+50 \% \mathrm{~N}$ & 84.2 & 85.1 & 3.58 & 3.57 & 46.1 & 47.2 \\
\hline L.S.D at $5 \%$ & 0.72 & 0.87 & 0.15 & 0.08 & 0.12 & 0.12 \\
\hline
\end{tabular}

earliest cultivar to begin flowering (33.6 and 34.9 days) followed by $c v$. Jaguar (46.2 and 47.3 days) and finally by cv. Palmoral (56.8 and 57.7 days) in the first and second seasons, respectively.

\section{Effect of bio and mineral nitrogen fertilization}

Illustrated data in Table 3 indicate that inoculation of the soil with bacterial isolate 1 plus fertilization with $50 \%$ mineral nitrogen recorded the tallest plants $(88.3$ and $90.4 \mathrm{~cm}$ ), followed by treatment which included the inoculation with isolate 2 plus $50 \%$ nitrogen fertilizer without significant differences between them during the two seasons of study, while the shortest plants were obtained from plants which treated with bacterial isolate 3 and without mineral nitrogen fertilization which gave 67.3 and 69.3 $\mathrm{cm}$ in the first and second seasons, respectively. As for number of branches per plant it is clear from the same data that the combination between isolate 1 or isolate 2 plus $50 \%$ mineral nitrogen increased significantly number of 
branches per plant and recorded 4.24 and 4.10 and 4.17 and 4.02, respectively, while the lowest values in this respect were recorded by the combination between isolate 3 without addition mineral nitrogen fertilization (2.73 and 2.80) in the first and second seasons, respectively.

Concerning flowering time, it is obvious from the data in Table 3 that the combination between isolates 1 and 2 without addition mineral nitrogen fertilization helped pea plants to flower earlier in the first season without significant difference, while the combination between isolate 2 and without mineral nitrogen fertilization helped pea plants to flower earlier in the second season (45.6 days). On the other side, fertilization of pea plants with mineral nitrogen at $100 \%$ of recommended dose led to delaying flowering of plant (46.7 and 47.3 days) in the first and second seasons, respectively.

\section{Effect of the interaction between pea cultivars, bio and mineral nitrogen fertilization:}

Results in Table 4 illustrate that the interaction between inoculation of pea plants of Palmoral cultivar with isolate 1 plus fertilization with $50 \%$ mineral nitrogen increased significantly plant height $(97.2$ and $99.5 \mathrm{~cm})$ and number of branches per plant (5.23 and 5.36) followed by inoculation seeds of Palmoral cultivar with isolate 2 plus fertilization with $50 \%$ mineral nitrogen $(96.2$ and $98.3 \mathrm{~cm})$ for plant height and (4.95 and 5.13) for number of branches per plant in the first and second seasons, respectively, without significant differences between them. On the other side, the lowest values in this respect were recorded by the interaction between inoculation seeds of Master B cultivar with isolate 3 and without mineral nitrogen fertilization which gave 58.8 and $61.3 \mathrm{~cm}$ for plant height and (1.83 and 1.76) for number of branches per plant in the first and second seasons, respectively.

As for flowering time, the same results in Table 4 indicate that the interaction between inoculation plants of Master B cultivar with isolate 1 and without mineral nitrogen fertilization recorded the lowest values of flowering time (32.1 and 33.6 days) in the first and second seasons, respectively, while the highest values in this respect were recorded by the interaction between Palmoral cultivar and fertilization of $100 \%$ mineral nitrogen which recorded 58.1 and 58.6 days in the first and second seasons, respectively.

\section{Yield and Its Components Effect of cultivars}

It is obvious from the data presented in Table 5 that Palmoral cultivar recorded the highest values of yield and its components expressed as number of pods per plant average pod weight, number of seeds per pod, 
Table 4: Effect of interaction between bio- and/or mineral $\mathrm{N}$ fertilization on growth characters of three pea cultivars during 2010/2011 and 2011/2012 seasons.

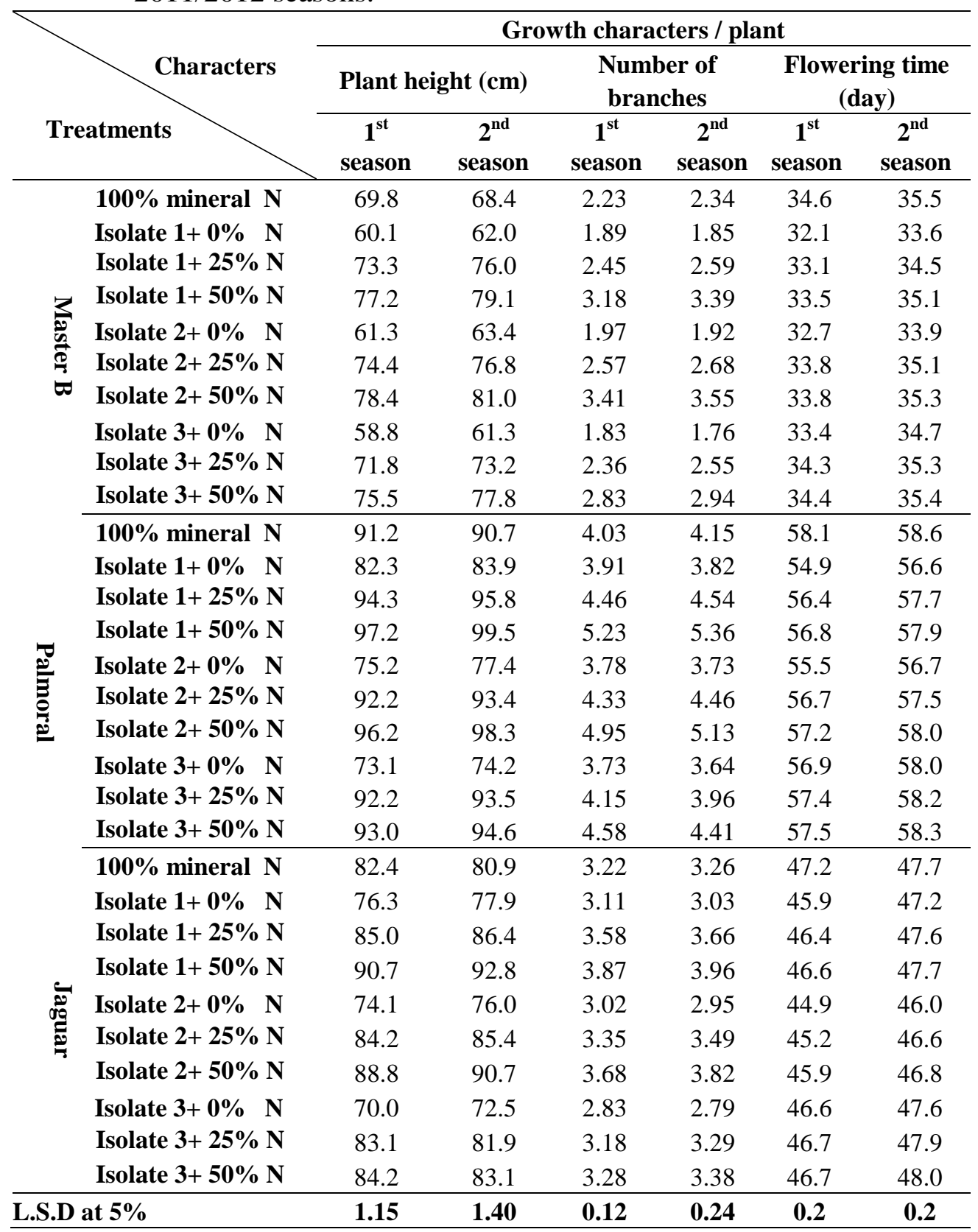


weight of 1000 seeds, yield per plant and green pods yield per feddan as well as dry seed yield per feddan. On the other hand, the lowest values in this respect were recorded by Master B cultivar in both seasons of study.

\section{Effect of bio and mineral nitrogen fertilization:}

Illustrated data in Table 5 indicate that inoculation pea plants with bacterial isolate 3 plus fertilization with $50 \%$ mineral nitrogen of the recommended dose recorded the highest number of pods per plant, while inoculation pea plants with the same bacterial isolate and without mineral nitrogen fertilization recorded the lowest values in this respect in the two seasons of growth. On the other side, inoculation pea plants with bacterial isolate 1 plus fertilization with $50 \%$ mineral nitrogen recorded the highest values of average pod weight (6.64 and $6.92 \mathrm{~g}$ ), number of seeds per pod (9.35 and 9.91), weight of 1000 seeds (215.8 and $236.8 \mathrm{~g}$ ), pods yield per plant (92.29 and $98.90 \mathrm{~g}$ ) and green yield per feddan (6.15 and 6.59 ton) as well as dry seed yield per feddan (1.247 and 1.303 ton) in the first and second seasons, respectively, while the lowest values in this respect were recorded when inoculated pea plants with bacterial isolate 3 and without mineral nitrogen fertilization, these results are true in both seasons of study.

\section{Effect of the interaction between pea cultivars, bio and mineral nitrogen fertilization}

Data in Table 6 illustrate that the interaction between inoculation of Palmoral cultivar plants with isolate 1 plus fertilization with $50 \%$ mineral nitrogen increased significantly yield and its components of pea plants as compared to other treatments, and recorded (15.70 and 15.92) for number of pods per plant, 7.01 and $7.39 \mathrm{~g}$ for average pod weight, 9.32 and 9.72 for number of seeds per pod, 232.7 and $253.7 \mathrm{~g}$ for weight of 1000 seeds, 109.7 and $117.7 \mathrm{~g}$ for yield per plant and 7.32 and 7.85 ton for green yield per feddan as well as 1.493 and 1.543 ton for dry seed yield per feddan in the first and second seasons, respectively. On the other side, the interaction between inoculation of Jaguar cultivar seeds with bacterial isolate 3 and without mineral nitrogen fertilization recorded the lowest values for number of pods per plant (9.11 and 9.57) and number of seeds per pod (5.37 and 5.76) in the first and second seasons, respectively, while the interaction treatment between inoculation plants of Master B cultivar seeds with bacterial isolate 3 and without mineral nitrogen fertilization recorded the lowest values of average pod weight, weight of 1000 seeds, yield per plant and green yield per feddan as well as dry seed yield per feddan, these results are true in both seasons of study. 
Table 6: Effect of interaction between bio- and/or mineral $\mathrm{N}$ fertilization on yield and its components of three pea cultivars during 2010/2011 and 2011/2012 seasons

\begin{tabular}{|c|c|c|c|c|c|c|c|c|c|c|c|c|c|c|c|}
\hline \multirow{3}{*}{$\mathbf{T}$} & \multirow{3}{*}{ Characters } & \multicolumn{14}{|c|}{ Yield and its components } \\
\hline & & \multicolumn{2}{|c|}{$\begin{array}{c}\text { No. } \\
\text { of } \\
\text { Pods } \\
\text { /plant }\end{array}$} & \multicolumn{2}{|c|}{$\begin{array}{c}\text { Average } \\
\text { pod } \\
\text { weight } \\
\text { (g) }\end{array}$} & \multicolumn{2}{|c|}{$\begin{array}{c}\text { No. } \\
\text { of } \\
\text { Seeds } \\
\text { /pod }\end{array}$} & \multicolumn{2}{|c|}{$\begin{array}{c}\text { Weight } \\
\text { of } 1000 \\
\text { seeds } \\
\text { (g) }\end{array}$} & \multicolumn{2}{|c|}{$\begin{array}{l}\text { Yield/ } \\
\text { plant } \\
\text { (g) }\end{array}$} & \multicolumn{2}{|c|}{$\begin{array}{l}\text { Green } \\
\text { yield } \\
\text { /fed. } \\
\text { (ton) }\end{array}$} & \multicolumn{2}{|c|}{$\begin{array}{c}\text { Dry } \\
\text { seed } \\
\text { yield/fed. } \\
\text { (ton) }\end{array}$} \\
\hline & & $1^{\text {st }}$ & $2^{\text {nd }}$ & $\mathbf{1}^{\mathrm{st}}$ & $\begin{array}{l}2^{\text {nd }} \\
s^{*}\end{array}$ & $\mathbf{1}^{\mathrm{st}}$ & $\begin{array}{l}2^{\text {nd }} \\
s^{*}\end{array}$ & $1^{\text {st }}$ & $\begin{array}{c}2^{\text {nd }} \\
\mathbf{S}^{*}\end{array}$ & $\begin{array}{l}1^{\text {st }} \\
\mathrm{s}^{*}\end{array}$ & $\begin{array}{l}2^{\text {nd }} \\
S^{*}\end{array}$ & $\mathbf{1}^{\text {st }}$ & $2^{\text {nd }}$ & $1^{\text {st }}$ & $2^{\text {nd }}$ \\
\hline \multirow{10}{*}{$\underset{\mathbb{0}}{\stackrel{2}{2}}$} & $100 \%$ mineral $\mathrm{N}$ & 12.83 & 13.05 & 5.10 & 5.31 & 8.49 & 9.00 & 170.7 & 190.6 & 65.5 & 66.1 & 4.37 & 4.63 & 0.803 & 0.863 \\
\hline & Isolate $1+0 \% \mathrm{~N}$ & 9.27 & 11.05 & 4.40 & 4.51 & 6.73 & 7.15 & 145.1 & 163.9 & 40.9 & 49.1 & 2.73 & 3.32 & 0.453 & 0.513 \\
\hline & Isolate $1+25 \% \mathrm{~N}$ & 10.44 & 11.27 & 6.18 & 6.39 & 9.48 & 9.88 & 184.7 & 203.7 & 64.6 & 72.1 & 4.31 & 4.81 & 0.763 & 0.813 \\
\hline & Isolate $1+50 \% \mathrm{~N}$ & 11.25 & 11.93 & 6.51 & 6.69 & 10.2 & 10.7 & 188.9 & 208.0 & 73.4 & 79.8 & 4.89 & 5.32 & 0.913 & 0.973 \\
\hline & Isolate $2+0 \% \mathrm{~N}$ & 9.79 & 10.89 & 4.66 & 5.00 & 6.96 & 7.39 & 153.7 & 174.9 & 45.7 & 54.6 & 3.05 & 3.64 & 0.503 & 0.563 \\
\hline & Isolate $2+25 \% \mathrm{~N}$ & 10.49 & 11.28 & 6.39 & 6.57 & 9.67 & 10.2 & 188.7 & 207.0 & 67.1 & 74.2 & 4.48 & 4.95 & 0.823 & 0.883 \\
\hline & Isolate $2+50 \% \mathrm{~N}$ & 11.37 & 11.67 & 6.89 & 7.12 & 10.5 & 10.8 & 201.9 & 222.6 & 78.4 & 83.2 & 5.23 & 5.55 & 0.983 & 1.053 \\
\hline & Isolate $3+0 \% \mathrm{~N}$ & 8.90 & 9.61 & 3.91 & 4.09 & 6.53 & 6.93 & 130.9 & 148.7 & 34.9 & 39.4 & 2.33 & 2.63 & 0.423 & 0.463 \\
\hline & Isolate $3+25 \% \mathrm{~N}$ & 11.82 & 12.27 & 5.19 & 5.43 & 9.18 & 9.59 & 179.7 & 199.8 & 61.4 & 66.7 & 4.07 & 4.45 & 0.713 & 0.773 \\
\hline & Isolate $3+50 \% \mathrm{~N}$ & 12.87 & 13.21 & 5.41 & 5.60 & 9.78 & 10.2 & 187.1 & 205.6 & 69.7 & 74.1 & 4.65 & 4.94 & 0.863 & 0.923 \\
\hline \multirow{10}{*}{ 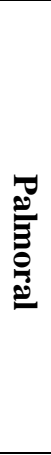 } & $100 \%$ mineral $\mathrm{N}$ & 15.57 & 15.77 & 6.11 & 6.29 & 7.68 & 8.17 & 184.8 & 205.1 & 95.2 & 99.3 & 6.35 & 6.62 & 1.243 & 1.293 \\
\hline & Isolate $1+0 \% \mathrm{~N}$ & 10.62 & & 5.71 & 5.89 & 6.51 & 6.89 & & 188.9 & 57.3 & 69.4 & 4.05 & 4.63 & & 1.093 \\
\hline & Isolate $1+25 \% \mathrm{~N}$ & 14.99 & 15.22 & 6.59 & 6.90 & 8.06 & 8.45 & 215.9 & 237.9 & 98.9 & 105.1 & 6.59 & 7.01 & 1.283 & 1.353 \\
\hline & Isolate $1+50 \% \mathrm{~N}$ & 15.65 & 15.92 & 7.01 & 7.39 & 9.32 & 9.72 & 232.7 & 253.7 & 109.7 & 117.7 & 7.32 & 7.85 & 1.493 & 1.543 \\
\hline & Isolate $2+0 \% \mathrm{~N}$ & 10.73 & 11.37 & 5.19 & 5.38 & 6.18 & 6.57 & 154.7 & 173.9 & 55.7 & 61.6 & 3.72 & 4.11 & 0.953 & 1.003 \\
\hline & Isolate $2+25 \% \mathrm{~N}$ & 14.81 & 15.47 & 6.29 & 6.47 & 8.20 & 8.60 & 204.9 & 224.0 & 93.2 & 100.1 & 6.22 & 6.68 & 1.223 & 1.263 \\
\hline & Isolate $2+50 \% \mathrm{~N}$ & 15.50 & 15.73 & 6.72 & 6.88 & 8.92 & 9.60 & 223.7 & 240.9 & 104.2 & 108.2 & 6.95 & 7.22 & 1.423 & 1.473 \\
\hline & Isolate $3+0 \% \mathrm{~N}$ & 10.93 & 11.07 & 4.78 & 4.99 & 5.89 & 6.32 & 144.9 & 163.7 & 52.3 & 55.3 & 3.49 & 3.69 & 0.833 & 0.893 \\
\hline & Isolate $3+25 \% \mathrm{~N}$ & 15.56 & 15.33 & 5.70 & 6.01 & 7.79 & 8.29 & 197.8 & 215.6 & 88.7 & 92.2 & 5.92 & 6.15 & 1.083 & 1.143 \\
\hline & Isolate $3+50 \% \mathrm{~N}$ & 15.70 & 16.51 & 6.29 & 6.38 & 8.28 & 9.22 & 215.9 & 232.1 & 98.8 & 105.4 & 6.93 & 7.03 & 1.343 & 1.383 \\
\hline \multirow{11}{*}{ ڤ్ } & $100 \%$ mineral $\mathrm{N}$ & 14.49 & 14.46 & 5.50 & 5.78 & 7.49 & 7.90 & 179.7 & & 79.7 & 83.6 & 5.32 & 5.58 & 1.073 & 1.133 \\
\hline & Isolate $1+0 \% \mathrm{~N}$ & 9.88 & 10.68 & 4.89 & 5.08 & 6.02 & 6.49 & 165.7 & 185.5 & 48.4 & 54.2 & 3.23 & 3.62 & 0.863 & 0.913 \\
\hline & Isolate $1+25 \% \mathrm{~N}$ & 12.57 & 13.18 & 6.09 & 6.34 & 7.86 & 8.48 & 201.7 & 225.2 & 76.6 & 83.6 & 5.11 & 5.58 & 1.163 & 1.213 \\
\hline & Isolate $1+50 \% \mathrm{~N}$ & 14.63 & 14.85 & 6.40 & 6.68 & 8.57 & 9.37 & 225.9 & 248.7 & 93.7 & 99.2 & 6.25 & 6.62 & 1.333 & 1.393 \\
\hline & Isolate $2+0 \% \mathrm{~N}$ & 9.52 & 10.41 & 4.76 & 4.93 & 5.79 & 7.52 & 150.7 & 169.8 & 45.4 & 51.4 & 3.03 & 3.43 & 0.723 & 0.773 \\
\hline & Isolate $2+25 \% \mathrm{~N}$ & 12.64 & 13.67 & 5.77 & 6.04 & 7.75 & 8.41 & 195.1 & 214.7 & 73.0 & 76.6 & 4.87 & 5.11 & 0.933 & 1.053 \\
\hline & Isolate $2+50 \% \mathrm{~N}$ & 13.64 & 14.14 & 6.18 & 6.41 & 8.28 & 9.06 & 214.0 & 233.0 & 80.4 & 90.7 & 6.03 & 6.04 & 1.243 & 1.293 \\
\hline & Isolate $3+0 \% \mathrm{~N}$ & 9.11 & 9.57 & 4.48 & 4.61 & 5.37 & 5.76 & 135.7 & 154.9 & 40.9 & 44.2 & 2.73 & 2.95 & 0.613 & 0.653 \\
\hline & Isolate $3+25 \% \mathrm{~N}$ & 13.51 & 13.75 & 5.19 & 5.36 & 7.48 & 8.23 & 188.9 & 207.6 & 70.1 & 73.7 & 4.68 & 4.92 & 0.933 & 0.983 \\
\hline & Isolate $3+50 \% \mathrm{~N}$ & 14.18 & 14.54 & 5.61 & 5.79 & 7.70 & 8.37 & 201.8 & 219.2 & 79.6 & 84.2 & 5.31 & 5.62 & 1.173 & 1.223 \\
\hline & L.S.D at $5 \%$ & 0.58 & 0.60 & 0.04 & 0.05 & 0.52 & 0.51 & 5.0 & 5.2 & 5.73 & 3.62 & 0.16 & 0.51 & 0.054 & 0.051 \\
\hline
\end{tabular}




\section{Chemical Constituents of Seeds Effect of cultivars}

It is obvious from the data presented in Table 7 that Palmoral cultivar recorded the highest values of total nitrogen percentage (3.78 and 4.28), potassium (2.26 and $2.35 \%$ ) and crud protein (23.63 and $26.75 \%$ ) in the first and second seasons, respectively, while Master B cultivar recorded the highest values of phosphorus $(0.317$ and $0.385 \%)$ and gave the lowest values of nitrate $(135$ and $141 \mathrm{mg} / \mathrm{kg})$ and nitrite $(5.48$ and $5.78 \mathrm{mg} / \mathrm{kg})$ in the first and second seasons, respectively.

\section{Effect of bio and mineral nitrogen fertilization}

Illustrated data in Table 7 indicate that inoculation pea plants with bacterial isolate 2 and fertilization with $50 \%$ mineral nitrogen recorded the highest values of total nitrogen (4.07 and 4.57\%), potassium (2.36 and $2.46 \%$ ) and protein (25.43 and $28.56 \%$ ) in the first and second seasons, respectively, followed by inoculation with bacterial isolate 3 and fertilization with $50 \%$ mineral nitrogen without significant differences between them. On the other side, inoculation pea plants with bacterial isolate 1 without mineral nitrogen fertilization recorded the lowest values of nitrate $(111$ and $113 \mathrm{mg} / \mathrm{kg})$ and nitrite $(4.79$ and $5.02 \mathrm{mg} / \mathrm{kg})$ in the first and second seasons, respectively.

\section{Effect of the interaction between pea cultivars, bio and mineral nitrogen fertilization}

Data in Table 8 illustrate that the interaction between inoculation pea plants of Palmoral cultivar with bacterial isolate 3 plus fertilization with $50 \%$ mineral nitrogen increased significantly chemical constituents of pea seeds as compared to other treatments, it recorded 4.33 and $4.85 \%$ for total nitrogen, 0.306 and $0.428 \%$ for phosphorus and 27.08 and $29.24 \%$ for protein, while seed inoculation of the same cultivar with bacterial isolate 1 and fertilization with $50 \%$ mineral nitrogen gave the highest values of potassium percentage (2.58 and $2.65 \%)$ in the first and second seasons, respectively. On the other side, inoculation plants of Master B cultivar with bacterial isolate 3 without mineral nitrogen fertilization recorded the lowest values of nitrate $(98$ and $101 \mathrm{mg} / \mathrm{kg}$ ) and nitrite content $(3.65$ and 3.93 $\mathrm{mg} / \mathrm{kg}$ ) in the first and second seasons, respectively.

\section{DISCUSSION}

Pea is a very nutritious vegetable grown in the cool season and it grown as a vegetable crop for both fresh and dried seed. It contains high percentage 
Table 8: Effect of interaction between bio- and/or mineral $\mathrm{N}$ fertilization on chemical constituents of 2010/2011 and 2011/2012 seasons cultivars during three pea

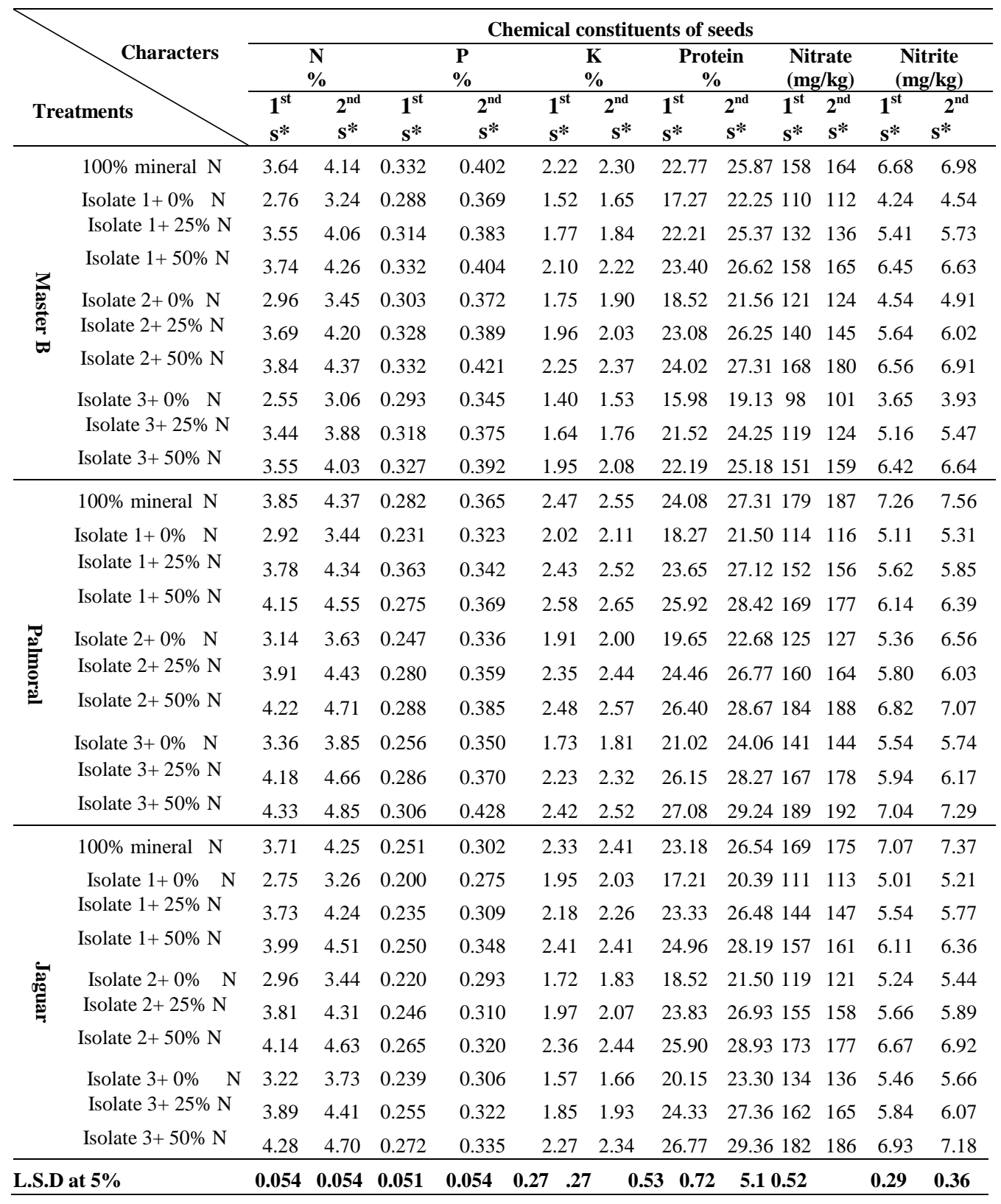


of digestible protein, along with carbohydrates and vitamins. That's why we chose this crop here to evaluate novel pea cultivars newly grown under the Egyptian winter growing conditions. Master B is a commonly known cultivar and it is a very early maturing cultivar suitable for mechanic harvesting, and Jaguar and Palmoral cultivars are recently imported British cultivars which are highly yielding peas cultivars. The later ones are sweeter than Master B and are very promising pea cultivars to be grown under the Egyptian conditions. The obtained results in this work confirmed all these characteristics of these cultivars and confirmed the previous results.

It is crucial to mention here that all the bio-fertilization isolates used here are produced in Minia university (The centre of Bio-fertilization, Minia University, Egypt.). The isolates used in this work are three promising products of this centre.

The bio-fertilization isolates treatments increased all horticultural characteristics, fresh pod yield and dry seed yield. Furthermore, they increased the protein content and decreased the nitrate and nitrite contents in dry seeds. So, the obtained seeds from bio-fertilized treatments are organic and safe in their content of nitrate and nitrite. That's because bio-fertilizers are important components of integrated nutrients management. They play a key role in productivity and sustainability of soil and also protect the environment (ElKalla et al. 1997; Sharma and Nanadeo, 1999; Hewedy, 1999). They are cost effective, eco-friendly and renewable source of plant nutrients to supplement chemical fertilizers in sustainable agricultural system (Abraham and Lal, 2002; Anany, 2002; Estefanous et al., 2003). Moreover, beneficial microorganisms in bio-fertilizers accelerate and improve plant growth along with protecting plants from pests and diseases which also enhances growth and increases yield (Abou El-yazeid et al., 2007). Moreover, soil microorganisms have a great role in sustainable development of agriculture and this has been reviewed by Lee and Pankhurst (1992) and Wani et al. (1995).

Obtained results showed that, using the combination of bio-fertilizers and half dose of mineral nitrogen gave the best results. Many authors showed that the favourable effect of Azotobacter and mineral nitrogen fertilizer on growth, chemical composition of leaves, and yield was reported on sugar beet (Stajner et al., 1997), on cauliflower (Bambal et al., 1998), and on faba bean (Wyszkowska, 1999). Also, Dakhly et al. (2004) on squash obtained the highest total yield and the best $\mathrm{N}$ uptake by using $45 \mathrm{~kg}$ nitrogen and chicken manure in addition to inoculation with Azotobacter. Prabhjeet et al. (1994) on Brassica napus and Verma et al. (1997) on cabbage, Verma et al. (2000) on pea and Panwar et al. (2000) on radish claimed that both inoculation with Azotobacter and application of $\mathrm{N}$ increased seed yield. 
Other scientists claim that bio-fertilizers increased the concentration of simple organic molecules such as sugars, free amino acids and total soluble phenols which played a role in regulation of plant osmosis and consequently better plant growth and yield (Panwar et al. (2000) and Verma et al. (2000). In other words, bacteria in bio-fertilizers can produce different compounds such as organic acids, plant growth promoters (auxins, gibberellins and cytokinins) as well as nitrogen fixing, dissolving phosphorus and producing organic acids in the soil which consequently lowers soil $\mathrm{pH}$ and increases the availability of most of the plants needed elements (Hanafy et al., 2000). In addition, the beneficial effects of bio-fertilizers such as production of organic acids (lowering soil $\mathrm{pH}$ ) and production of plant growth regulators may contribute to a better plant growth and yield through enhancing nutrient uptake (Ibrahim and AbdelAziz, 1977). On the other hand, it is well known that bio-fertilizers can lower the amount of added chemical nitrogen fertilizer to the soil and consequently mitigation of pollution (Ibrahim and Abdel-Aziz (1977). All these statements were clear and confirmed by the obtained results.

Conclusively, the three promising pea cultivars showed very desirable characteristics e.g., short time to flowering, high yield of fresh fruits and dry seeds. The bio-fertilization increased the used cultivars potentials of growth, protein content and dry seed production and also decreased the seeds content of nitrate and nitrite.

The best results were obtained when the $50 \%$ of the recommended mineral nitrogen dose was used along with the bio-fertilization isolates as compared to the other treatments and the control treatment. These results encourage Egyptian pea farmers to produce the organic pea as the demand for organic pea is increasing in the Egyptian markets and also for exportation along with enhancing sustainable agricultural system in Egypt.

\section{REFERENCES}

AOAC (2005). Official Methods Of Analysis, Association of Analytical Chemists $18^{\text {th }}$ ed, Washington, DC.

Abou El-Yazeid, A.A., H.A. Abou-Aly, M.A. Mady and S.A.M. Moussa (2007). Enhancing growth, productivity and quality of squash plants using phosphate dissolving microorganisms (bio phosphor) combined with boron foliar spray. Res. J. Agric. Biol. Sci., 3(4): 274-286.

Abraham, T. and Lal R.S. (2002). Sustainable enhancement of yield potential of mustard (Brassica junce (L.) Czern. Coss) through integrated nutrient management (INM) in a legume based cropping system for the inceptisols. Cruciferae Newsletter, 24: 99-100. 
Akhilesh K. P. and S. Singh (2013). Assessment and genetic variability in garden pea (Pisum sativum L. var. Hortense). International J. Agric. Sci., 9 (1): 293-296.

Anany, T.G. (2002). Effect of some agricultural treatments on growth and dry seeds yield of beans. Ph. D. Thesis, Faculty of Agricultural Science, Zagazig University (Benha Branch), Moshtohor, Egypt.

Bambal, A.S., R.M. Verma, D.M. Panchbhai, V.K. Mahorkar and R.N. Khankhane (1998). Effect of bio-fertilizers and nitrogen levels on growth and yield of cauliflower (Brassica oleracea var. botrytis). Orissa J. Hort., 26: 14-7.

Brown, J. and O. Lilliland (1946). Rapid determination of potassium and sodium in plant material and soil extracts by flame photometer. Proc. Amer. Soc. Hort. Sci., 48: 341- 346.

Dakhly O. F., Y.T. Abdel Mageed and E.A. Hassan (2004). Effect of nitrogen, organic fertilizers and new Azotobacter transformants on squash. Minia J. Agric. Res. Develop., 24: 1-30.

Davies, D.R., G.J. Berry, M.C. Heath, and T.C. Dawkins (1985). Pea (Pisum sativum L.) Grain Legume Crops. Ch 5. Collins, London.

El-Agory, E., S. Allam, N.O. Monged and A.K.H. Ahmed (1996). A comparative study on using biofertilizers and micronutrients to reduce the rate of mineral $\mathrm{N}$-fertilizer for wheat plant on sandy soil. Egypt. $J$. Appl. Sci., 11: 286-300.

El-Kalla, S.E., A.K. Mostafa, A.A. Leilah and R.A. Awad (1997). Mineral and bio-phosphatic fertilization for inter-cropped faba bean and onion. Egypt. J. Agric. Res., 77: 253-71.

Estefanous, A.N., O.M. Sawan and A.F. Abou Hadid (2003). Effect of inoculation with phosphate-bacteria, sawdust compost and nitrogen sources on okra yield and some properties of calcareous soil. Acta Hort., 608: 85-94.

Gad El-Hak, S.H., A.M. Ahmed and Y.M.M. Moustafa (2012). Effect of foliar application with two antioxidants and humic acid on growth, yield and yield components of peas (Pisum sativum L.). J. Hort. Sci. and Ornamental Plants, 4 (3): 318-328.

Gheeth, R. H.M, Y.M.M. Moustafa and W.M. Abdel-Hakeem (2012). Ascorbic acid and cobalt chloride enhanced growth and increased production of peas. J. Novel Appl. Sci., 2(4):106-115.

Gomez, K.A. and A.A. Gomez (1984). Statistical Procedures For Agricultural Research. John Willey and Sons. New York, Second Ed. PP. 680. 
Hanafy, A. A.H., J.F. Mishriky and M.K. Khalil (2000). Reducing nitrate accumulation in lettuce (Lactuca sativa L.) plants by using different biofertilizers. Paper Presented in the ICEHM, Conference, Cairo University, Egypt, September, 2000.

Hewedy, A.M. (1999). Influence of single and multi-bacterial fertilizer on the growth and fruit yield of tomato. Egypt. J. Appl. Sci., 14: 508-523.

Ibrahim, A.N. and I.M. Abdel-Aziz (1977). Solubilization of rock phosphate by Streptomyces. Agro. Talajton, 26: 424-434.

John, M.K. (1970). Colorimetric determination of phosphorus in soil and plant material with ascorbic acid. Soil Sci.,109: 214-222.

Lee, K.E. and C.E. Pankhurst (1992). Soil organisms and sustainable productivity. Australian J. Soil Res., 30: 855-892.

Marschner, H. (1995). Mineral Nutrition of Higher Plants. Academic press, London, $4^{\text {th }}$ printing., pp: 889.

Mithen, S. (2003). After the Ice: A Global Human History 20,000-5,000 BC. Weidenfield and Nicholson, London.

Panwar, A.S., J.S. Balyan and V.S. Verma (2000). Yield and quality of radish (Raphanus sativus) seed as affected by fertility levels and biofertilizers. Indian J. Agron., 45: 822-826.

Prabhjeet. S, S.C. Bhargava and P. Singh (1994). Change in growth and yield components of Brassica napus L. in response to Aztobacter inoculation at different rates of nitrogen application. J. Agric. Sci., 122: 241-247.

Pregl, E. (1945). Quantitative Organic Micro Analysis. $4^{\text {th }}$ Ed. J. Chundril, London.

Saad, O.A. (1991). Influence of soil temperature on the microbial population metabolizing nitric oxide. Ph. D. Thesis, Microbiol. Dept., Fac. Agric., Minia Univ., Egypt.

Saber, M.S.M. (1993). A multi-strainn biofertilizer. Paper Presented in the Sixth International Symbosiumon Nitrogen Fixation with NonLegumes. Ismailia, Egypt 6-10 September.

Sharma, K.N., and K.N. Namdeo (1999). Effect of bio-fertilizer and phosphorus on growth and yield of soybean (Glycine max (L.) Merrill). Crop Res. Hisar, 17: 160-163.

Stajner D., S. Kevresan, O. Gasic, N. Mimica-Dukic and H. Zongli (1997). Nitrogen and Azotobacter chroococcum enhance oxidative stress tolerance in sugar beet. Biol. Plant., 39: 441-445.

Verma, O.P., P. Sangeeta, M.S. Rathi and S. Paul (2000). Synergistic effect of co-inoculation of Azotobacter chrooccum and Rhizobium on pea (Pisum sativum). Annals Agric. Res., 21: 418-420.

Verma, T.S., P.C. Thakur and S. Ajeet (1997). Effect of bio-fertilizers on vegetable and seed yield of cabbage. Vegetable Sci., 24: 1-3. 
Wani, S.P., T.G. Rego, S. Rajeshwari and K.K. Lee (1995). Effect of legume-based cropping systems on nitrogen mineralization potential of Vertisol. Plant Soil, 175(2): 265-274.

Wilde, S.A., Corey, R.B., Lyer, J.G. and G.K. Voigt(1985). Soil and Plant Analysis for Tree Culture. Mohan Primlani, Oxford, IBH Publishing Company. New Delhi, pp 1-42.

Wyszkowska, J. (1999). Modification of faba bean chemical composition caused by precursors of growth regulators and soil microorganisms. III. Effect of precursors of ethylene. Biuletyn Naukowy, 5: 75-82.

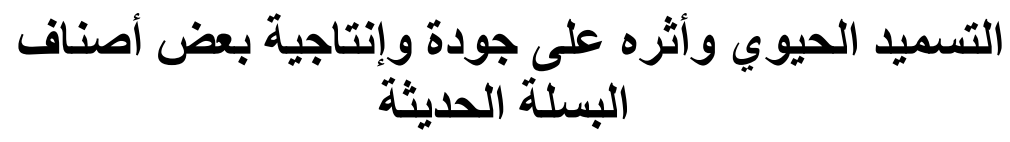

وائل محمد عبد الحكيم' ، ياسر محمود محمد مصطفى ' ، خالد عطية محمود نور'

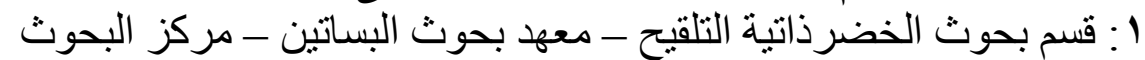

الزر اعية - جمهورية مصر العربية.

ب: قسم البساتين (فرع الخضر اعنة) - كلية الزر اعة - جامعة المنيا - جمهورية

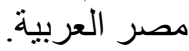

تم استخدام ثناثة أصناف من البسلة (صنف قديم وهو Master B وداف وصنفان

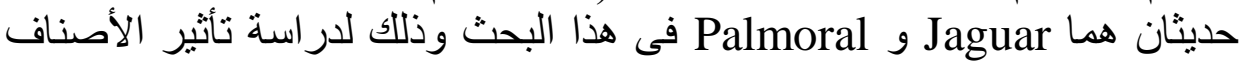

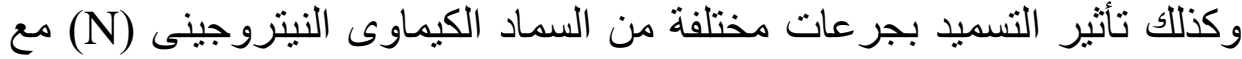

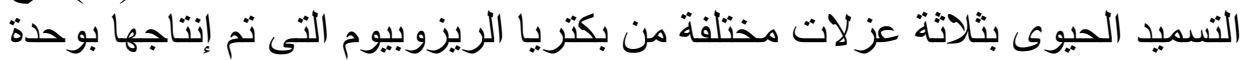

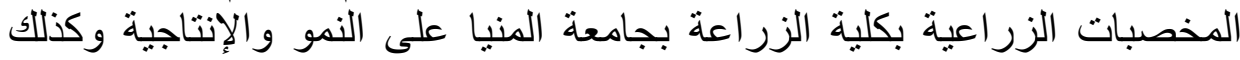

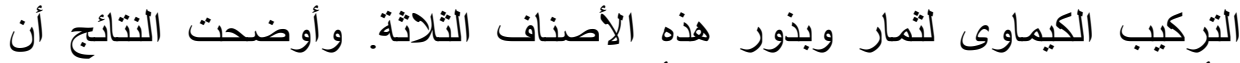

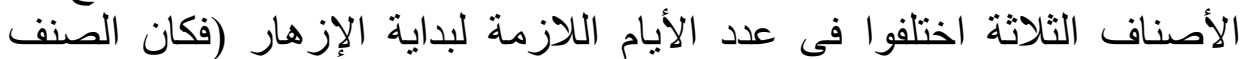
Master M

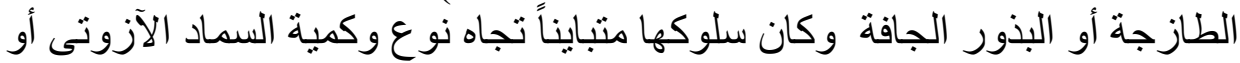

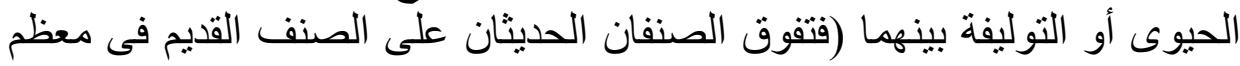

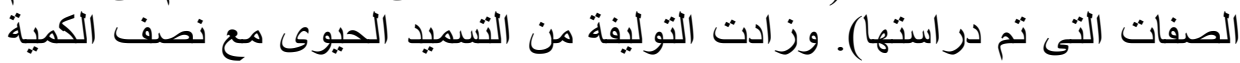

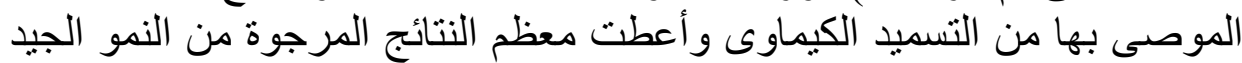
و المحصول العالى من القرون و البذور وكذلك محتوى البذور العالى العي من البروتين. 
ومن الناحية الأخرى قلل التسميد الحيوى معنوياً من محتوى البذور من النترات والنيتريت بالمقارنة بتلك المأخوذة من النباتات التى تم تسميدها بالسماد الكيماوى من التئ فقط.

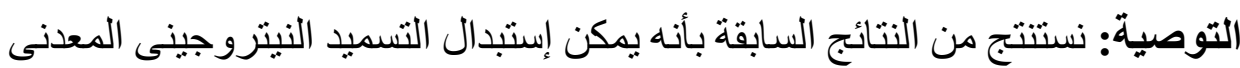

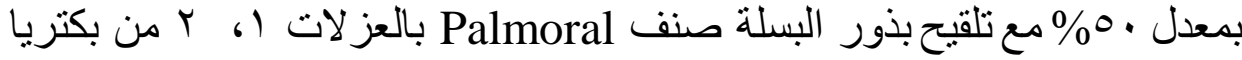

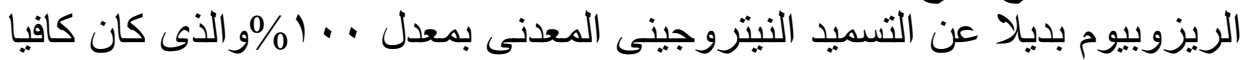

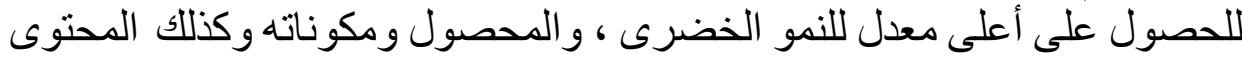
الكيماوى لبذور البسلة.

أ.د/ المتولى عبد السميع الغمرينى ـ أستاذ الخضر - جامعة الزقازيق أ.د/ فتحى أبو النصر أبـو سديـره ـ أستاذ الخضر - - جامعة بنها
} 